\title{
READING, DEVOTION AND RELIGIOUS PRINT IN EARLY CINQUECENTO NAPLES. THE CASE OF FRANCESCO SOVARO'S CHRISTIADE ${ }^{1}$
}

\author{
Marco Faini
}

\section{Domestic devotion and books}

Recent years have witnessed a flourishing of studies on early modern Italian religion, fostered by the opening of the Archive of the Sant'Uffizio. Whilst scholars have extensively explored the spread of heterodoxy and the work of institutions like the Roman Inquisition, we still lack a systematic insight into the practices of private devotion. Such a focus seems increasingly desirable since it allows us to shed light on actual beliefs. The household appears to be the place where authentic religiosity was fully displayed. Everyday religion was often marked by the intertwining of orthodox and superstitious practices; needless to say, the house was also the only place where heretics felt safe enough to practice their own cults. The complexity of Italian religiosity is testified to by an incredibly rich variety of objects: books, paintings, amulets, agnus $D e i{ }^{2}$ rosaries, brevi, blessed candles etc. It was only after the council of Trent that authorities felt the need to impose some order on such a varied experience. The Acta of the synods, regularly printed from the second half of the sixteenth century, the series of Acta criminalia held in episcopal and archiepiscopal archives, and inquisitorial correspondence all help us to get a sense of how multifaceted domestic devotion was.

Books were of course part of domestic devotion: yet, the role of devotional print in early modern Italy, particularly of popular books, still awaits a comprehensive study focusing on their manifold nature as complex devotional objects provided with talismanic, protective, didactic and devotional powers. ${ }^{3}$ The high number of Leggende, miracoli, orazioni, fiori di virtù, religious epics, vernacular versions of the Bible, particularly of the Psalms, spiritual poems, cannot be explained merely in terms of commercial strategy in response to the Inquisitorial policies that had restricted the print market. Rather, it most likely met the needs and the tastes of a wide audience.

Religious books could be involved in everyday devotion in many ways. They recounted devout stories and facts, thus providing the readers with exempla of virtue; they could be used as a primer (this is the case with the many Giardini and Giardinetti spirituali); they could even be worn like a piece of clothing or a talisman in order to assure oneself protection. ${ }^{4}$ Most of all, they supplied

\footnotetext{
${ }^{1}$ This article draws on research conducted for the project funded by the European Research Council and hosted by the University of Cambridge, Domestic Devotions: the Place of Piety in the Renaissance Italian Home, 1400-1600 (PIs Abigail Brundin, Deborah Howard, Mary Laven).

${ }^{2}$ The figure of the Lamb bearing a cross or a banner casted in blessed wax that had protective and sometimes talismanic powers.

${ }^{3}$ Besides the works by Jacobson Schutte, Quondam, Barbieri cited in this work, one can also resort to: Lorenzo Baldacchini, Bibliografia delle stampe popolari religiose del XVI-XVII secolo. Biblioteche Vaticana, Alesandrina, Estense (Florence: Olschki, 1980); Id., 'Il libro popolare italiano d'argomento religioso durante la Controriforma', in Le Livre dans l'Europe de la Renaissance, Actes du XXVIII ${ }^{\mathrm{e}}$ Colloque international d'Etudes humanistes de Tours, sous la directions de Pierre Aquilon et Henry J. Martin, avec la collaboration de François Dupuigrenet Desrousilles (Paris: Promodis, 1988), pp. 434-445; Ugo Rozzo, Linee per una storia dell'editoria religiosa italiana (1465-1600) (Udine: Arti Grafiche Friulane, 1993); Mario Chiesa, 'Poemi biblici fra Quattro e Cinquecento', Giornale Storico della Letteratura Italiana, 179 (2002), pp. 161-192; Gabriella Zarri, 'Note su diffusione e circolazione di testi devoti (15201550)', in Libri, idee e sentimenti religiosi nel Cinquecento italiano, 3-5 aprile 1986, (Modena: Panini, 1987), pp. 131154; Giorgio Caravale, L'orazione proibita. Censura ecclesiastica e letteratura devozionale nella prima età moderna, (Florence: Olschki, 2003).

${ }^{4}$ See for example a rare fly sheet entitled Oratione devotissima alla matre di Dio trovata nel S. Sepolcro di Christo (in Barzellona, e ristampata inVenetia, con licenza de' Superiori): “Questa S. Oratione fu trovato [sic] nel S. Sepolcro di Christo in Gerusalem, qualsivoglia Christiano che la porta con devotione dicendo un'Ave Maria ogni giorno non avrà paura di sententia di Giudici contro di sé a tortamente, né morirà in acqua, né foco, né falso testimonio potrà contro di
} 
enjoyable versions of the Bible, particularly of the New Testament, and thus proved to be a formidable tool to get people acquainted with the Holy Scripture, especially after the prohibition of its vernacular translations by the Congregation of the Index. ${ }^{5}$

In this essay I will focus on one of these works, a vernacular poem on the life of Christ which has been all but forgotten: the Christiade written by the Neapolitan poet, physician and philosopher Francesco Sovaro. ${ }^{6}$ The poem has been disregarded and neglected by scholarship since the seventeenth century. Niccolò Toppi, in his Biblioteca napoletana (1678) described Sovaro as a "poeta di qualche nome"; Francesco Saverio Quadrio simply mentioned his name in his monumental Della storia e della ragione d'ogni poesia (1739-1752). At the end of eighteenth century, Lorenzo Giustiniani laconically wrote that the Christiade was a "rare book"; one century later, Camillo Minieri Riccio briefly recorded Sovaro's name defining him "rinomato" whilst, according to Erasmo Pèrcopo, Sovaro's work was made up of "cinquantatré rozzissimi canti". Vincenzo Cicchitelli was even ashamed to mention the work: "dovrei ora parlare del poema del Sovaro, ma di esso preferisco di tacere, poiché non credo si possa ritenere degno di considerazione un rozzo volgarizzamento in terza rima degli evangeli." "7 Nor was Benedetto Croce more enthusiastic about this work which was, in his opinion, "tutt'altro che un bel poema sacro" so that "quando si è detto che l'opera del Sovaro è un'arida e frigida versificazione del Nuovo Testamento, è detto tutto". ${ }^{8}$ In Antonio Altamura's view, Sovaro's Christiade "è pedissequamente ricalcata dai Vangeli, senza che un soffio di poesia [...] dia vita e movimento artistico al prolisso componimento in terza rima". ${ }^{9}$

As far as I know, Sovaro was mentioned in positive terms only by the eighteenth-century scholar Giovanni Bernardino Tafuri, who referred to him as a man "di non poca intelligenza, particolarmente nelle cose Toscane, e molto amato da tutti i Letterati, che in que' tempi erano nella città di Napoli sua Patria". 10

I argue here that this poem deserves critical reassessment. As I will demonstrate, it is a sort of unicum that can be better appreciated if considered in the light of private and domestic devotional practices in early Cinquecento Naples. My hypothesis is that the Christiade can be better understood as a piece of devotion than a purely literary work. In other words, it seems to me that Sovaro's purpose was mainly didactic. Sovaro, in choosing a plain style (though reminiscent of

sé, né morirà di pesta $[\mathrm{sic}]$, né rabia, et in ciascuna battaglia sarà sempre vincitore. Se alcuna donna non potrà partorire, mettendol sopra questa oratione subito partorirà. Vale contro l'indemoniati e portando sempre questa oratione addosso gli apparirà la Madonna santissima et è cosa esperimentata dalli signori Inquisitori di Barzellona", my emphasis.

5 Andrea Del Col, 'Appunti per una indagine sulle traduzioni in volgare della Bibbia nel Cinquecento italiano', in Libri, idee e sentimenti religiosi, pp. 165-188; Edoardo Barbieri, Le Bibbie italiane del Quattrocento e del Cinquecento. Storia e bibliografia ragionata delle edizioni in lingua italiana dal 1471 al 1600 (Milan: Editrice Bibliografica, 1992); Gigliola Fragnito, La Bibbia al rogo. La censura ecclesiastica e i volgarizzamenti della Scrittura (1471-1605) (Bologna: il Mulino, 1997); Ead., Proibito capire. La Chiesa e il volgare nella prima età moderna (Bologna: il Mulino, 2005).

${ }^{6}$ Sovaro is not mentioned among the Lecturers of the Neapolitan Studio in Carlo De Frede, Docenti di filosofia $e$ medicina nella Università di Napoli dal secolo XV al XVI (Naples: Tipografia De Frede, 2001). His date of birth is unknown: he died after 1539.

${ }^{7}$ Cfr. Niccolò Toppi, Biblioteca napoletana (Naples: Antonio Bulifon, 1678), p. 96; Francesco Saverio Quadrio, Della storia e della ragione d'ogni poesia (Milan: Francesco Agnelli, 1749), vol. IV, p. 212; Lorenzo Giustiniani, Saggio storico critico sulla tipografia del Regno di Napoli (Naples: Vincenzo Orsino, 1793), p. 140 (the numbering is highly incorrect); Camillo Minieri Riccio, Memorie storiche degli scrittori nati nel Regno di Napoli (Naples: Tipografia dell'Aquila, 1884), p. 335; Erasmo Pèrcopo, review of Gaetano Moroncini, Sulla "Cristiade” di M.G. Vida (Trani: Vecchi, 1896), Rassegna della Letteratura italiana, 1 1896, pp. 115-117 (p. 117); Vincenzo Ciochitelli, Sulle opere poetiche di Marco Girolamo Vida (Naples: Luigi Pierro e figlio, 1904), p. 391.

${ }^{8}$ Benedetto Croce, 'La "Cristiade" di Francesco Sovaro', in Id., Aneddoti di varia letteratura, vol. 1 (Bari: Laterza, 1953), pp. 194-196 (pp. 194-195).

9 Antonio Altamura, L'Umanesimo nel Mezzogiorno d'Italia. Storia, bibliografie e testi inediti (Florence: Bibliopolis, 1941), pp. 152-153 (p. 152). Recently, Élise Boillet shortly mentioned the poem in her book on Pietro Aretino and the Bible: Élise Boillet, L'Arétin et la Bible (Genève: Droz, 2007), p. 48.

${ }^{10}$ Giovanni Bernardino Tafuri, Istoria degli scrittori nati nel Regno di Napoli, vol. 3, parte I (Naples: Mosca, 1750), pp. 324-325. 
Dante), adopting the vernacular, and providing the text with paratextual elements, purportedly rejected the solemn and classicizing approach to the New Testament chosen by other authors (for example, Marco Girolamo Vida's Christias, a Latin poem on the life of Christ first published in 1535, a Christian re-writing of Virgil's Aeneis). Sovaro preferred to faithfully render the evangelical text; what is more, the choice of terza rima can be explained as a response to the need to memorize the work or, rather, to memorize its devotional contents. Thus, I will demonstrate why and to what extent this work can be thought of as a devotional object. ${ }^{11}$

In order to better understand Sovaro's work, I will set it in the context of Neapolitan spiritual and religious life as well as of contemporary religious poetry and print culture. Through a comparison with other printed texts, I will aim to show the peculiarities of Sovaro's text. I will take into account not only works printed in Naples, but also works printed elsewhere in Italy and circulated within the Kingdom in order to build a reliable picture of devotional reading in early Cinquecento Naples. I will also try to demonstrate how the book might be considered a prompt response to the circulation of heterodox ideas in Naples in the 1530s.

\section{The Neapolitan context: religion and spirituality}

Religious life in Naples in the sixteenth century was extremely lively: only a few years before Sovaro printed his poem, some of the most prominent members of the local aristocracy had gathered around the Spanish reformer Juan de Valdés, among them, noblewomen including Giulia Gonzaga and Vittoria Colonna. Fervid discussions of science were going on the circle of Scipione Capece, whose friend Basilio Sabazio at the beginning of the decade denied traditional Thomist cosmology on the basis of his experimental observation of comets; what is more, anabaptist, antitrinitarian and Lutheran ideas were widely spread. ${ }^{12}$

The trial of the Marchigian priest Pietro Manelfi gives us a an impressive overview of the intense circulation of heretical ideas between Naples and the Venetian Terraferma. In Padua, "Messer Bruno Busale, napolitano, scolaro, et tre altri nella sua habitatione, anabattisti. Geronimo Busale [...] si partì da Padova et passò al padre a Napoli per rinontiare gli benefici acciò fosse accettato nella compagnia degli anabattisti. [...] Anchora soggionse don Pietro haver parlato et connosciuto con messer Giovanni napolitano et messer Benedetto pur da Napoli, quali negano il vangelo con tutto il testamento nuovo, dicendo essere cosa da gentile, et dice che tal setta et compagnia è in Napoli". ${ }^{13}$ On the 13th of November 1551 Manelfi was questioned and provided an alarming (for the Inquisitors) picture of the spread of heterodoxy in Naples:

la chiesa d'anabattisti di Padoa [...] li mandorno a Napoli acciò havessero da insegnare e predicare ivi questa dottrina anabattista [...]. Item andorno anchora a Napoli quelli dua canonici di Pola ch'hieri dissi [...]. Quanto alli Lutherani de Napoli, ho inteso da diversi, et Lutherani et anabatisti che son andati a Napoli et per altri luoghi, che ivi sono molti et molti Lutherani et assai, secondo m'hanno detto [...] Item ho inteso da messer Benitto neapolitano qual adesso studia in Padoa di medicina, il settembre passato o circa, essendo alhora io anchora in Padoa, che in Napoli è una nova seta d'heretici in gran moltitudine, et de primi di Napoli, li quali tra l'altre heresie loro tengono Christo non essere Dio ma

\footnotetext{
${ }^{11}$ Sovaro is also the author of an unpublished vernacular translation of the Psalter now (presumably) held in the Biblioteca dei Girolamini of Naples under the title of Lo officio de la Madona. Vulgare, con l altri [sic] ordinato da Franc. Sovaro. As a manuscript, this work was intended to be circulated within a restricted, possibly familiar circle. Interestingly, according to Altamura, in this work one can find "una maggiore vivacità di stile e d'ispirazione" than in Sovaro's major work. See Altamura, L'Umanesimo nel Mezzogiorno, p. 152. Unfortunately, the manuscript is currently unavailable for consultation.

${ }^{12}$ On the spread of antitrinitarian ideas in Naples see Aldo Stella, Dall'anabattismo al socinianesimo nel Cinquecento Veneto. Ricerche storiche (Padua: Liviana, 1967); Id., Anabattismo e antitrinitarismo in Italia nel XVI secolo. Nuove ricerche storiche (Padua: Liviana, 1969). On Basilio Sabazio see Franco Bacchelli, 'Sulla cosmologia di Basilio Sabazio e Scipione Capece', Rinascimento, 30 (1990), pp. 107-152.

${ }^{13}$ Carlo Ginzburg, I costituti di don Pietro Manelfi (Florence-Chicago: Sansoni-The Newberry Library, 1970), pp. 4547.
} 
gran propheta et non essere venuto come messia ma come propheta, et essere morto per la verità, et che non è anchora risuscitato [...] anzi negano tutto il testamento novo et dicono essere inventione di Greci et Gentili et che Paolo non ha inteso niente delle scriture vechie, maxime circa la giustificatione et resurrecione, perché dice la giustificatione essere per il sangue et meriti di Christo, et la scrittura dice la giustificatione essere per misericordia de Dio. ${ }^{14}$

The great Inquisitorial trials of the 1550s provide us with a well-articulated and detailed picture of religious dissent in the Kingdom of Naples. The origins of this religious turmoil can be traced back to the period following Valdés' arrival in the city in 1535:

Dopo la venuta di Valdes in Napoli con la corte dell'Imperatore nel 1535, successe nell'anno 1540 ch'un certo heremitano di santo Agostino, apostata, siciliano, detto don Lorenzo Romano, in habito di frate venne a Caserta, et, fatta ivi scuola di molti gentil'huomini, infettò quel paese. ${ }^{15}$

Caserta was one of the breeding grounds of heresy: "Non solo Caserta, ma anche tutto il contorno era appestato d'heresia" and the city of Naples itself after the death of Paul IV witnessed a new rise of heterodoxy: "Nel 1562 Napoli, sì per la libertà delle passate guerre, come anche perché dopo la morte di Paolo IV gli heretici presero animo et forze, stava molto infecta d'heresie". ${ }^{16}$ In 1567 , according to a Lista di abiurati, nominati e sospetti di heresia di Caserta et convicini cavata da diversi processi napoletani now held in the Archive of the Sant'Uffizio in Rome, there were 104 heretics in Caserta and the nearby towns. ${ }^{17}$

The chronicle of Antonino Castaldo enables us to understand how heretical ideas took root in Naples. The year 1539, when Sovaro published his work, was a turning point. In that year the General Chapter of the Augustinian friars was held in Naples and Girolamo Seripando appointed General of the Congregation. On that occasion, many Augustinian theologians held public disputations, among them Giovanni da Montalcino, who used to read St. Paul's epistles and was later executed as a heretic in Rome. In the very same year, Pietro Martire Vermigli read St. Paul's epistles in the church of S. Pietro ad Aram, raising the suspicions of the religious authorities by calling into question the existence of Purgatory, to the extent that he was suddenly prevented from preaching. Bernardino Ochino had preached in Naples in 1536 to great acclaim, "per lo suo nuovo modo di predicare l'Evangelio, non con dispute filosofiche, e stravaganze [...] ma con spirito, con veemenza, e con fervore mirabile". ${ }^{18}$ In 1539 he came back to Naples to preach in the Archbishop's Palace, but his preaching was ambiguous and provoked in-depth discussions at all levels of society about such delicate issues as Grace and justification by faith. According to Castaldo, even tanners were publicly disputing St. Paul's epistles. ${ }^{19}$ Even worse was the fact that after Ochino's flight, many families were left secretly "infected" by heresy. ${ }^{20}$ Castaldo's statement hints at a double level of diffusion of heterodox ideas, a public one and a private and secret - if not nicodemite - one, which one might reasonably suppose to be connected with the domestic sphere, given the ambiguity of the term case. Following Castaldo, at the time a number of books by Erasmus, Melanchton and, particularly, the Beneficio di Cristo, was being sold and publicly read. ${ }^{21}$ One of Ochino's main

\footnotetext{
${ }^{14}$ Ibid., pp. 68-69. On the spread of anabaptist ideas in Naples see Luca Addante, Eretici e libertini nel Cinquecento italiano (Rome-Bari: Laterza, 2010).

${ }^{15}$ Massimo Firpo, Il processo inquisitoriale del cardinal Giovanni Morone. Edizione critica, vol. 1, Il compendium (Rome: Istituto storico italiano per l'Età moderna e contemporanea, 1981), p. 227.

${ }^{16}$ Ibid., p. 228.

${ }^{17}$ Cf. Massimo Firpo, La presa di potere dell'Inquisizione romana 1550-1553 (Rome-Bari: Laterza, 2014$)$, p. 120.

${ }^{18}$ Dell'istoria di notar Antonino Castaldo libri quattro [...] (Naples: Giovanni Gravier, 1769), p. 73.

19 "Le sue prediche diedero campo e cagione a molti di parlare della Sacra Scrittura, di studiar gli Evangelj, e disputare intorno la giustificazione, la fede, le opere, la potestà pontificia, il Purgatorio [...]. Ed io dirò una cosa, che parrà incredibile ed è pur verissima, che insino ad alcuni coriari della conceria al Mercato era venuta questa licenza di parlare e discorrere dell'Epistole di San Paolo, e de' passi difficoltosi di quelle", Ibid., p. 74.

20 "Ma quel che fu peggio, lasciò la costui dottrina, come in ogn'altra parte d'Italia avea fatto, molte persone e Case infette d'occulto morbo eretico", Ibid.

21 “A quel tempo uscirno in stampa senza nome dell'autore certi libretti, uno de' quali fu il Sommario della Scrittura; l'altro il Beneficio di Cristo, con alcune opere di Filippo Melantone, e di Erasmo, tutti pieni di empietà e d'eresie. I
} 
opponents was Ambrogio Salvio, a Dominican friar, preacher and confessor of Charles V, who even challenged Ochino to a public dispute. Ochino's preaching on the most debated and controversial issues raised by the Reformation had fascinated many Neapolitans. ${ }^{22}$ Yet, even more alarming than his sermons were the small booklets that he circulated widely, which were avidly read and passed from the hand to hand. ${ }^{23}$ As these books represented a threat even after Ochino's flight, Salvio decided to gather them in front of the Cathedral and burn them. ${ }^{24}$ It is likely that the circulation of such books might have prompted Sovaro to try his hand at writing his Christiade, which consists of a poetical synopsis of the four Gospels. The circulation of dangerous interpretations of the Gospel could thus be counterbalanced with an easily accessible version of the Gospel itself, presented in its purity.

Among those who gathered to listen to Pietro Martire Vermigli's preaching was Galeazzo Caracciolo, marquis of Vico, who later fled to Geneva and converted to Calvinism. In the 1530s, his spiritual anguish had just begun and his soul was under attack by two dreadful enemies: the anabaptists and the Valdesians. As Niccolò Balbani, Caracciolo’s biographer, put it,

About that time the Realme of Naples was sore pestred with Arrians and Anabaptists: who daily broched their heresies amongst the common people, colouring them over with glorious shewes;

but, according to Balbani

The devil had not so done with him, for another and more dangerous battell presently followed. The Waldesians of whom wee spake before, were at that time in Naples in good number. With them did Galeacius daily converse, their courses of life and study being not farre unlike. These Disciples of Waldesius knew as yet no more in Religion but the point of Justification: and misliked and eschewede some abuses in Popery; and neverthelesse still frequented Popish Churches; heard Masses, and were present ordinarily at vile Idolatries. ${ }^{25}$

Although we lack a comprehensive history of the Neapolitan church, it is well known that, along with heresy, blasphemy, superstition, magical-diabolical practices, profane and pagan rituals and other beliefs meshed with Christian ceremonies were also flourishing in the city. ${ }^{26}$ Bishops always failed in their attempts to educate Neapolitans to a greater respect for orthodoxy. The long-lasting and steadfast opposition to the Inquisition caused religious authorities to lose their grasp on the local population. As Giovanni Romeo put it, "the need to combat the excesses of an ungovernable metropolis did not produce any serious reform aimed at educating Neapolitans to a greater respect for orthodoxy". ${ }^{27}$ Nor was it easy for the authorities to intervene in the immense territory of the

quali libri, perché molti mesi senza proibizione de' Superiori, per non averne tenuto conto, pubblicamente si vendevano, e leggevano, furono perniziosi ad alcuni", Ibid.

${ }^{22}$ Ochino's sermons contained statements "non guari sane, e toccanti ora la grazia, ora li Sacramenti, il Purgatorio, il culto delle sacre Immagini, l'autorità del Papa e somiglievoli altre materie", Sebastiano Pauli, Della vita del venerabile monsignore F. Ambrogio Salvio dell'ordine de' predicatori [...] (Benevento: nella Stamperia Arcivescovile, 1716), p. 44.

23 'Lasciò correre per le mani de' suoi favoreggiatori alcuni libri di poca mole, ma colmi di molto veleno [...]. Non può già dirsi quanto strabocchevole anzhi che no fusse l'applauso col quale furono essi ricevuti, letti e studiati. Passavano da una in un'altra mano e stimavasi fortunato colui che ne potea aver copia", Ibid., p. 45.

24 "Non contento della censura con cui furono essi condannati, ottenne ancora che tutti ad un fascio si portasssero avanti la porta della Chiesa madre, ed ivi dopo aver contro d'essi assai lunge e dottamente perorato, si abbrugiassero", Ibid., pp. 47-48.

${ }^{25}$ The italian convert. Newes from Italy of a second Moses or the life of Galeacius Caracciolus [...] (London: printed by A.G., 1635), pp. 13-14. Balbani was himself a Calvinist; the work first appeared in Geneva in 1587, in Italian. See Carlo Ginzburg, 'Balbani, Niccolò (Nicolao)', in Dizionario biografico degli Italiani (Rome: Istituto dell'Enciclopedia italiana, 1963), vol. 5, pp. 336-342.

${ }^{26}$ See for example the list of trials causae Religionis drawn by the notary Joele in 1580-1581 published in Luigi Amabile, Il Santo Officio della Inquisizione in Napoli (Città di Castello: Lapi, 1892), vol. II: Documenti, pp. 10-12.

${ }^{27}$ Giovanni Romeo, Inquisition and Church in early modern Naples, in A Companion to early modern Naples, ed. by Tommaso Astarita (Leiden-Boston: Brill, 2013), pp. 235-255 (p. 246). One can also resort to Ernesto Pontieri, 'Le origini della Riforma cattolico-tridentina a Napoli. (Note ed appunti)', in Problemi di vita religiosa in Italia nel 
Kingdom: if the massacre of the Valdesian community in Calabria in 1561 is well known, it has also been established that Greek and Albanian communities managed to survive and to remain entirely independent from the Roman Church. ${ }^{28}$ According to his autobiography, Giulio Antonio Santoro, who was later to become Sommo inquisitore, as late as 1557 had to fight against the Lutherans who were still on the rise. ${ }^{29}$

\section{Religious books in Naples: print, circulation and the book-trade}

Naples was a rather unusual area in Italy and many of the heterodox ideas that spread all over the Peninsula migrated from the Kingdom of Naples to the Venetian Terraferma. Though the number of religious books printed in Naples in the fifteenth and sixteenth centuries is not particularly high, it is safe to assume that the need for religious works was widespread. Records exist of the wide circulation of such works through a lively network of librai from the fifteenth century onwards. According to Mariano Fava and Giovanni Bresciano's pioneering article on I librai ed $i$ cartai di Napoli nel Rinascimento, 154 booksellers and book traders were active in the Kingdom over the course of the fifteenth century. The trade in books from and to Naples was also flourishing. As early as 1482 a certain Giovanni di Giovanni from Augusta, who was a bookseller based in Perugia, was accorded the privilege to go around the Kingdom of Naples "vendendi libros impressos". ${ }^{30}$ On the 13th of May, 1480, Antonio Venetus, a bookseller, was granted license to ship to the Lanciano fair "certam quantitatem librorum impressorum seu de stampa". ${ }^{31}$ On the 9th of September 1474 Alessandro de Calcedoniis had twelve boxes of books shipped from Venice to Naples "ibidem ad stampam confectorum"; 32 on the 7th of February, 1483, Paolo di Giovanni, Venetian, imported books from Venice to sell them in the city of Cosenza. ${ }^{33}$ Religious books played a central role in this trade. In 1491 Guglielmo Condel established a society with Giovannotto Arcella in order to produce "voluminum septingentarum breviarium"; the seven hundred breviaries were successively shipped to Valencia, to Gualterino and Luis Garzia. ${ }^{34}$ In 1487, Antonio Martino de Oyra bought on behalf of Tommaso Baroni of Naples certain books from Matteo di Giorgio from Sebenico, among which a "Bibliam unam magnam de carta de pergameno pro maiori parte meniatam et hystoriatam". 35

Many of the librai active in Naples came from Venice and the Veneto. Even though from the 1570s until the end of sixteenth century printing houses were established in 26 cities of the Kingdom, the book-trade was massively influenced by the Venetian output. According to Corrado Marciani, about

Cinquecento, Atti del convegno di Storia della Chiesa, Bologna, 2-6 settembre 1958 (Padua: Antenore, 1960), pp. 289313; Mario Rosa, 'La Chiesa meridionale nell'età della Controriforma', in Storia d'Italia, Annali, vol. 9, La Chiesa e il potere politico dal Medioevo all'età contemporanea, A cura di Giorgio Chittolini e Giovanni Miccoli (Turin: Einaudi, 1986), pp. 291-345; Carlo De Frede, 'La diffusione delle idee riformate nel Mezzogiorno', in Id., Religiosità e cultura nel Cinquecento italiano (Bologna: il Mulino, 1999), pp. 1-14.

${ }^{28}$ See Pierroberto Scaramella, 'Inquisizioni, eresie, etnie nel Mezzogiorno d'Italia: il peccato in moltitudine', in L'Inquisizione e gli storici: un cantiere aperto, Tavola rotonda nell'ambito della conferenza annuale della ricerca, Roma, 24-25 giugno 1999 (Rome: Accademia nazionale dei Lincei, 2000), pp. 97-108.

29 'E crescendo tuttavia la setta de' luterani nel regno di Napoli m'armai contro di quella, spinto dal zelo della religione cattolica. E con ogni mio potere, e con l'autorità dell'officio, con le prediche pubbliche e scritte da me in un libro detto Quadragesimale, e con le dispute pubbliche e private in ogni occasione, e con l'oratione cercai d'abbattere et esterminare peste sì crudele da i miei paesi. Onde patii acerbissima persecutione dagli heretici, che per tutte le strade cercavano d'offendermi e d'ammazzarmi.", Giuseppe Cugnoni, 'Autobiografia di mons. G. Antonio Santori cardinale di S. Severina', Archivio della R. Società di Storia patria, 12 (1889), pp. 327-372 e 13 (1890), pp. 151-205 (p. 335 ).

${ }^{30}$ Giocondo Ricciarelli, 'Mercanti di incunaboli a Perugia', Bollettino della Deputazione di Storia patria per l'Umbria, 70 (1973), pp. 1-20 (p. 4).

${ }^{31}$ Mariano Fava-Giovanni Bresciano, 'I librai ed i cartai di Napoli nel Rinascimento', Archivio storico per le Province napoletane, 43 (1918), pp. 89-104 e 253-270; 45 (1920), pp. 228-250; 59 (1934), pp. 324-373 (p. 242 ).

32 Ibid., p. 234.

${ }^{33}$ Ibid., p. 244.

${ }^{34}$ Ibid., pp. 267 and 333.

${ }^{35}$ Ibid., p. 354. 
a hundred Venetian librai, typographers and publishers were active in the Kingdom during the sixteenth century. ${ }^{36}$ Among these printers, some were well known, like Federico Torresani (who in 1557 asked that he be given all the money, goods and books that some debtors in Naples owed him), ${ }^{37}$ some have only recently been re-discovered, such as Giovanni Alberto Borgominerio da Trino, ${ }^{38}$ some were among the most influential of their time, like Gabriele Giolito de' Ferrari.

They usually had books shipped to Naples via the Marche and Umbria. In particular, books were sold and bought on the occasion of the huge fairs of Lanciano and Recanati. Printers and book traders generally established their storehouses in these places: from there, books were easily shipped or brought to the Kingdom.

The fair at Lanciano remained one of the most significant sites of book-trading for the duration of the sixteenth century: it was there that such prominent printers as Lucantonio Giunta, Vincenzo Valgrisi and Francesco Ziletti had their storehouses and local agents. One might suppose that religious books were also supplied from Venice to Naples via Lanciano. For example, we have a poliza of books belonging to Vincenzo Valgrisi that remained unsold and were thus shipped back to Venice on the 9th of June, 1559. Among them two copies of the Legende della Vergine, one Omiliario volgare, four Libri da batezar, one copy of the Confessioni by St. Antonino, and a copy of a Concordantia Bibliae. ${ }^{39}$

I have dealt with book-trade at length because it appears to be the case that, in order to understand what the most popular devotional books were in Naples, the book-trade represents a more reliable source of information than the annals of Neapolitan typographers. As Carlo De Frede has pointed out, only a few works related to the religious debates of the sixteenth century were printed in Naples. There are no Neapolitan editions of Erasmus, of Luther, or of the Italian reformers like, for example, the widely spread Beneficio di Cristo. Even the Bible was printed only once in Naples, in 1476: and this is a fact to bear in mind when considering the reasons that might have inspired Sovaro to write the Christiade. It is safe to say that the poem represents an exception in the panorama of Neapolitan printing. Nevertheless, in the period between 1542 and 1547, such works as, among other, Alfonso de Valdés' Dialogues, Luther's De servo arbitrio, Calvin's and Münster's works, and Curione's Pasquino in estasi were read and copied (and thus circulated in manuscript form) in Naples. ${ }^{40}$

The print market in Naples over the first three decades of the sixteenth century was allegedly free, to the point that it has been affirmed that anyone could print or have anything printed in the Kingdom without license. ${ }^{41}$ The freedom of the press in Naples may have been overstated, nevertheless, it was only after Pedro de Toledo's Prammatica sanzione in 1544 that control of the print market grew tighter. Before 1569, booksellers were required to present lists of their books to the ecclesiastical authorities. ${ }^{42}$ Moreover, in the second half of the century, the print market became

\footnotetext{
${ }^{36}$ See Corrado Marciani, 'Editori, tipografi, librai nel Regno di Napoli nel Cinquecento', Studi veneziani, 10 (1968), pp. 457-554. On the different roles of publishers, printers, editors, book-sellers, see Brian Richardson, Print culture in Renaissance Italy. The editor and the vernacular text 1470-1600 (Cambridge: Cambridge University Press, 1994); Id., Printing, writers and readers in Renaissance Italy (Cambridge: Cambridge University Press, 1999).

${ }^{37}$ Corrado Marciani, 'Il testamento, e altre notizie, di Federico Torresani', La Bibliofilia, 73 (1971), pp. 159-178 (p. 172).

${ }^{38}$ See Francesco Quarto, 'Uno sconosciuto editore del XVI secolo a Napoli: Giovanni Alberto Borgominerio da Trino', La Bibliofilia, 102 (2000), pp. 177-205.

${ }^{39}$ The document is published in Corrado Marciani, 'Il commercio librario alle fiere di Lanciano nel '500', Rivista storica italiana, 70 (1958), pp. 421-441 (pp. 434-435).

${ }^{40}$ Pasquale Lopez, Inquisizione stampa e censura nel Regno di Napoli tra '500 e '600 (Naples: Edizioni del Delfino, 1974), pp. 26-27.

41 "Ciascuno stampava e faceva stampare in questo Regno di Napoli quel che li piaceva senza licenza del Re, né de' Prelati e persone ecclesiastiche, così come in tutte le altre parti del mondo si faceva", Scipione Volpicella, 'Relazione delle stamperie e stampatori e proibizione de' libri per causa di giurisdizione', Archivio storico per le Province napoletane, 3 (1878), pp. 199-210, quoted also in Lopez, Inquisizione stampa e censura, p. 31.

${ }^{42}$ Ibid., p. 72.
} 
subject to the control of both the Viceroy and the religious authorities, as stated in the Synod of Mario Carafa in $1567 .{ }^{43}$

Despite increasing inquisitorial and vice-regal control Neapolitan printers or booksellers appeared on the Index only occasionally. ${ }^{44}$ All the same, local authorities exerted increasingly strict controls, as the 1565 trial of Giovanni Battista Cappello, who ran Giolito's shop, clearly shows. Cappello was denounced to the Inquisition and, following an inspection, nearly 200 prohibited books were discovered in his shop. From the inventory drawn up on that occasion, we get the sense of how much devotional literature was desired by the reading public. For example, alongside vernacular versions of the Bible, breviaries, spiritual poems and offices of the Virgin, almost all the hagiographic works by Pietro Aretino are listed. ${ }^{45}$ The authorities' interest in the book-trade is evident from over one thousand letters sent by the Inquisition to the tribunals of faith in Naples, recently published by Pierroberto Scaramella, where matters of prohibited books are also frequently intertwined with superstitions and the abuse of magic. ${ }^{46}$

\section{The Christiade as a didactic poem}

The Christiade was printed in Naples in March 1539 by the printer Mattia Cancer ("per Mathia Cance da Napoli, a di 4 de Marzo" according to the colophon) who had moved to Naples from a small town near Brescia, in Lombardy, where he was born. Cancer had established his printing house in $1529 .{ }^{47}$ According to Edit16, the poem was never reprinted and only two copies survive, one at the Biblioteca Nazionale in Naples (the one I used) and the other one at the University Library in the same city. Despite the large folio format and the wide margins of the pages, typical of high-quality works, the book is full of typographical errors, as testified to by the long erratacorrige. ${ }^{48}$ According to Sovaro, the reason why only the first part of the Christiade was published, is precisely the tiresome work he carried out amending the work. This could perhaps reinforce the hypothesis that the work was hastily published under the pressure of contemporary circumstances. The poem is written in terza rima and divided into fifty-three canti which, according to the original plan, should have been 106, as we know from the author's statement printed before the erratacorrige. Here, Sovaro announces the second part of the work containing, among others, the Acts of the Apostles:

la seconda parte: ne la quale con altri tanti capitoli ho scritto gli Atti de gli Apostoli, le Epistole canoniche e le historie degli Apostoli ponendo fine al Opra: con la Ascensione de la madre de Idio nel cielo: \& ivi se trovaranno le epistole

\footnotetext{
${ }^{43}$ The synod reiterated the rule according to which "Parlandosi dell'edizione de' libri, si ordina che non sieno impressi senza prima esser letti, essaminati ed approvati [...]. Ciò che anch'oggi si osserva giusta il Concordato da cui i Vescovi non si partono, lasciando intera a' Ministri regi la giurisdizione che ànno di leggere, essaminare ed approvare ciò che loro appartiene per gli diritti della Regalia. E nella nostra città questa costumanza è stata sempre interamente custodita, che l'ecclesiastica podestà non appruova mai ciò che lede la Real giurisdizione e la podestà laicale difende la Fede, la Religione ed il costume, non permettendo mai che libro s'imprima che possa nuocere a que' principi che farebbero per rovesciarla", Giuseppe Sparano, Memorie istoriche per illustrare gli atti della S. Napoletana chiesa [...], p. I (Naples: per Giuseppe Raimondi, 1768), pp. 251-252, my emphasis.

${ }^{44}$ See Carlo De Frede, 'Tipografi editori librai italiani nel Cinquecento coinvolti in processi di eresia', Rivista di Storia della Chiesa in Italia, 23 (1969), pp. 21-53; Id., 'La stampa a Napoli nel Cinquecento e la diffusione delle idee riformate', in La stampa in Italia nel Cinquecento, Atti del Convegno, Roma, 17-21 Ottobre 1989, a cura di Marco Santoro (Rome: Bulzoni, 1992), vol. II, pp. 753-773.

${ }^{45}$ All the documents pertaining the trial can be read in Salvatore Bongi, Annali di Gabriel Giolito de' Ferrari [...] (Rome: presso i principali librai, 1890), pp. LXXXV-CIX.

${ }^{46}$ See Pierroberto Scaramella, Le lettere della Congregazione del Sant'Ufficio ai tribunali di fede napoletani 1563 1625, prefazione di John Tedeschi (Trieste-Naples: Edizioni Università di Trieste-Istituto italiano per gli studi filosofici, 2002).

${ }^{47}$ Pietro Manzi, La tipografia napoletana del '500. Annali di Mattia Cancer ed eredi (1529-1595) (Florence: Olschki, 1972), pp. 48-49.

${ }^{48}$ De la Christiade di Francesco Sovaro Napolitano, col.: Stampata in Napoli, per Mathio Cance, a di 4 de Marzo del Anno del Signor 1539, cc. 124v-126r; the author himself complains about the "infiniti errori" (c. 124v).
} 
annotate con gli Evangeli, fuor che quelle di Paulo. Aspectati dunque con più correcte impressione, se Idio mi darà vita, tutta l'opra perfetta. 49

Sovaro's death prevented him from concluding the poem. Sovaro's work is an attempt to provide his readers not only with a poetic paraphrase of the four Gospels, but also with an useful tool in order to quickly get acquainted with the New Testament (at least according to the author's plans). One might suppose that he was primarily addressing a Neapolitan audience: in times of such spiritual turmoil, his poem was perhaps meant to be a reliable guide to the knowledge of the fundamental Christian texts. Sovaro's narrative technique is to construct a mosaic of passages from the four Gospels offering a sort of synoptic version of the life of Christ. Moreover, it presents the reader with a vernacular version, literally translated, of many passages of the New Testament and of the main Christian prayers. Whilst the printed marginalia to the text refer to the specific passages of the Gospel the author paraphrases, a Tavola at the end summarizes them in the form of a list. Here the reader can find the incipit of each passage of the Gospel read on each Sunday of the year, starting with the first Sunday of Advent ("ala prima messa", c. 7v, "ala I messa la notte di Natale", c. 8r). In the Tavola, the author makes specific reference to the capitolo in which each passage is mentioned so that the reader can easily find what he or she is interested in:

Signati ho anchora qui li Indici, curioso Lettore, per li quali agevolmente trovareti li Evangeli, giorno per giorno negli Capituli particulari; e come incominciano e finiscono incominciando da la prima Domenica del advento, per tutto l'Anno. ${ }^{50}$

Sometimes, the references to the Gospels are inserted within the text itself, as in the case of the Genealogy of Christ in canto IV where Sovaro directly addresses the reader:

Chi sua Geonologia intender brama

Matheo nel primo, al terzo Luca, al verso

La scrivon $[\ldots]$. ${ }^{51}$

Sovaro seems to be aware of some discrepancies between the Gospels and therefore warns his reader to be cautious and to ascertain the true meaning of the different passages which, in the end, harmonize with each other:

E se '1 si legge, Genitor diverso

Elì, e Giacob, da Iesca, non curare

Che l'un non scrisse mai da l'altro adverso.

Quel, per natura, s'ha da interpretare,

L'altro per legge, e concordi li fai. ${ }^{52}$

Sovaro provides his work with a summary of the contents, a Summa di zio [sic] che ne i Capitoli si contiene, and with an errata-corrige, which proves of the utmost utility, given the high number of typographical errors scattered within the text. As stated above, Sovaro also translates, entirely or partially, some of the most common Christian prayers, such as the Hail Mary (c. 4v), the Magnificat (c. 5r), the Benedictus or the so-called Song of Zechariah (c. 7r) and the Gloria in excelsis Deo (c. $8 \mathrm{v})$. These are the most evident didactic features of the Christiade. The author barely interrupts the narration of the life of Christ to comment on it or to address the reader. When he does so, it is usually in order to urge his reader to bear in mind what he has just read, or to encourage him to

\footnotetext{
${ }^{49}$ Ibid., c. $124 \mathrm{v}$.

${ }^{50}$ Ibid., c. $111 \mathrm{r}$.

${ }^{51}$ Ibid., c. $7 \mathrm{v}$.

${ }^{52}$ Ibid.
} 
perform good deeds, or, again, to adhere to Christ's example as much as he can, accepting God's will. Thus, referring to Zechariah's doubts, he comments as follows:

Che l'huom non de' dubiar quando a Dio piace

A la revelation de' suoi mandati

Ma dee accettargli in humilitade e pace. ${ }^{53}$

The work appears to be perfectly orthodox; even though the author touches upon a number of delicate issues, such as the value of good deeds for salvation, nevertheless he appears to be unconcerned with their rising importance within contemporary discussions. For example, in canto XXIII he inserts a (as we read in the final summary, c. 122v) «digressionetta» on good deeds:

Onde se l'opre son perfette e bone

Non bastan elle, né convien troncare

Per seguir lui ciò che al rio ve dispone.

La fermezza Christiana il buono oprare

Non solo dee: ma quel ch'è pronto al male

Tor via, o senza morbo tolerare

Fervente a l'opre buone esser non vale

S'huom non può la passion né vuol soffrire

Ch'è inferma e medicarsi allhor gli cale.

La cupidigia vana e il van disire

Ritragon l'opra buona e fan la inferma,

Tal che va senza fren l'huom a perire. ${ }^{54}$

As we can see, there is no allusion to the on-going debate on salvation through faith or through good deeds, nor can one find trace of it in the following lines: "Tra' popoli era ferma opinione / Colui che credea in Christo esser salvato.» 55

Sovaro sometimes enriches the original text, rhetorically supplementing it with long speeches attributed to Christ or St. John the Baptist. He therefore begs the reader to be indulgent with his work, repeatedly compared, resorting to a traditional metaphor, to a ship, lost and wandering among the storms of the vast sea that is the Gospel (for example at the beginning of canti XIII, XVII, XIX, $\mathrm{XXIV}, \mathrm{XLVII})$. It is also possible to find typical formulae deriving from chivalric romance, which seem to allude to some kind of oral performance of the text, as in the first lines of canto XVII:

Dunque tornar conviene a quel camino

Ove Giesù (ch'io ben me ne ricordo)

$[\ldots] .{ }^{56}$

Such passages, reconnecting different parts of the text, seems to allude at the existence of an audience other than that of readers. This seems to be likely, since the habit of common reading of devotional texts is very well documented. ${ }^{57}$

\footnotetext{
${ }^{53}$ Ibid. c. 6r.

${ }^{54}$ Ibid., c. 47r.

${ }^{55}$ Ibid., c. 15r. On the debate on salvation through Faith, see at least: Benedetto da Mantova, Il beneficio di Cristo con le version del secolo XVI, documenti e testimonianze, a cura di Salvatore Caponetto (Florence-Chicago: SansoniNewberry Library, 1972); Carlo Ginzburg-Adriano Prosperi, Giochi di pazienza. Un seminario sul 'Beneficio di Cristo' (Turin: Einaudi, 1975); Barry Collett, Italian Benedictine Scholars and the Reformation: The Congregation of Santa Giustina of Padua (New York: Clarendon-Oxford University Press, 1985); Massimo Firpo, Riforma protestante ed eresie nell'Italia del Cinquecento. Un profilo storico (Rome-Bari, Laterza, 1993); Massimo Zaggia, Tra Mantova e la Sicilia nel Cinquecento (Florence: Olschki, 2003).

${ }^{56}$ Sovaro, Christiade, c. 34v.

${ }^{57}$ See Fragnito, Proibito capire.
} 
Among the most remarkable digressions is the one found in canto XVIII on the etymological meanings of the names of the Apostles which, once more, appears to be perfectly in tune with the didactic purposes of the poem. Another notable digression is that of canto XXIV, in which the author compares the Pharisee and the Publican to two charioteers, whose horses are, metaphorically, Pride and Humility: a metaphor that seems reminiscent of Plato's theory of the soul as set out in the Phaedrus. ${ }^{58}$ Sovaro's philosophical background becomes evident in canto XXXIII, where he debates, curiously, on the nature of soul. The canto consists of a long digression aiming to explain the three parabolas mentioned in the previous chapter (those of the fig tree, of the two ploughmen and of the ten Virgins). Though the literal meaning is far from evident, Sovaro stresses here the importance of the balance between the senses and the intellect: when we cannot keep the right balance between these two, the soul is negatively affected ("Che quando il senso, l'intelletto offosca / Va l'huom pronto a gli tre stati rei / E così fassi l'alma inferma, e losca"). ${ }^{59}$ Sovaro warns the reader of the importance of knowing himself ("S'io trasgredendo faccio in ciò dimora / Sustienlo lettor mio, che molto vale / Saper cognoscer l'huom se stesso ogni hora"). ${ }^{60}$ Subsequently, he diverts from the narration to explain the nature of the soul, resorting to specific philosophical vocabulary: "Di lei [e.g. the soul] la conoscenza haver si deve / Doppia, et in la sustanza, e negli effetti, / O accidenti, e non può dirsi in breve"). ${ }^{61}$

Sovaro seems to be well aware of the hard task that his work represents: it is not at all easy to poetically rewrite the Gospels without betraying their theological content. Therefore, in canto L he assures the reader (and, possibly, the religious authorities?) that everything he has written, he has drawn from the Gospels ("Questo intesi, lettor, stando vicino / Di quattro Spiriti, ch'io me viddi attorno / Alhor che presi a far cotal camino"). ${ }^{62}$ Interestingly, the author seems here to pretend that he actually stood in the company of the four Evangelists, witnessing their metamorphosis into the four animali with which they are traditionally associated. From this, he claims, he drew all he knows of Christian mysteries: if he has mistakenly reported something about them, it is because of his "weak intellect" ("Più cose assai dicean, ch'io non capea / Misurando mio debile intelletto"). ${ }^{63}$ At the end of this canto, Sovaro declares his desire to write what happened after the Crucifixion and death of Jesus Christ. He asks the Holy Virgin, who has been his guide throughout the work, to assure him of her benevolence and help him in his strenuous new task. Sovaro seems to have been facing the difficulty of literally dealing with the mystery of the Trinity and with the doctrine of consubstantiation. This is suggested by the translation of the beginning of the Gospel of John, which he places in the last section of the canto. Remarkably, the version of John's Gospel is introduced by a very obvious quotation from Purgatorio XXIV, where Dante acknowledges the poetic novelty of the Stilnovo. Sovaro was presumably stressing the novelty of his own task:

Mi facci dir, ch'al dire non paia acerbo

Quel che tanto alto a tutto il mondo scrisse

Incominciando: In principio era il verbo. ${ }^{64}$

Interestingly, other traces of Sovaro's knowledge of Dante can be found throughout the poem: for example, in the episode of the sinner washing Christ's feet in the home of Simon the Pharisee one reads: "a lei, che mai da lui non si disgiunse". This line does not come from the evangelical source

\footnotetext{
${ }^{58}$ In the Phaedrus Plato represents the soul as a chariot dragged by two winged horses, representing the rational and the irrational forces of the human soul. The task of the charioteer, that is to say of man, is to keep the balance between these forces.

${ }^{59}$ Sovaro, Christiade, c. $67 \mathrm{v}$.

${ }^{60}$ Ibid.

${ }^{61}$ Ibid., c. $68 \mathrm{r}$.

${ }^{62}$ Ibid., c. $102 \mathrm{v}$.

${ }^{63}$ Ibid., c. 103 r.

${ }^{64}$ Ibid. Cf. Dante, Purg., XXIV, 49-51: "Ma di' s'i' veggio qui colui che fore / trasse le nove rime, cominciando / 'Donne ch'avete intelletto d'amore'".
} 
but rather, in my opinion, from Inferno V, 135: "questi che mai da me non fia diviso". ${ }^{65}$ Again, in one of Sovaro's apologies for his digressions, one reads as follows:

Solcavan l'onde le gonfiate vele

Quando s'accorse ch'el temone acanto

Lasciato havea quel mio nochier fedele.

Se da l'arengo fosse uscito alquanto

Non guidato dal fil del Labirinto

Lettor tu 'l scusa del'error non tanto

Ch'egli sarà più attento a stargli avvinto

Guardando ogni onda al tremolar marino

E d'oltra trapassar non così accinto. ${ }^{66}$

Here the expression "tremolar marino" clearly echoes Purgatorio I, 117, "il tremolar della marina". Sovaro's imitation of Dante, and the very choice of resorting to the terza rima, quite predictably, point to his attempt to match his Gospel sources with the most illustrious example of "sacrato poema" (Par., XXIII, 62).

Although Sovaro seems to be more concerned with the didactic and theological content of his poem than with its literary quality, his use of Dante seems to influence his style more than the theological nature of the poem. The overall Dantesque inspiration of the Christiade should also be assessed in light of the linguistic debates taking place in Naples in the 1530s. Bembo's theories were actively discussed though only partially accepted. Petrarch certainly remained the most influential and authoritative model, as testified to by the two contemporary commentaries on his Rime by Giovanni Andrea Gesualdo and Silvano da Venafro (1533; the latter was published by Cancer). Yet the canon proposed by Bembo was implemented by contemporary authors, as can be seen in Fabrizio Luna's Vocabolario (1536) or in Marc'Antonio Ateneo Carlino's La gramatica volgar (1533), in which Petrarch is joined by Sannazaro and Bembo himself. A few years later, in 1538, Tizzone Gaetano da Pofi, in his La grammatica volgare, included in the canon of the most excellent Italian poets both Guittone d'Arezzo and Cino da Pistoia. These various works demonstrate how Neapolitan culture, however receptive to Bembo's ideas, remained largely independent from them and pursued particular approaches to poetry. It was Benedetto Di Falco (d. c. 1568) who openly challenged Bembo's opinions on Dante's poetry, first in his Rimario (1535, Cancer) and subsequently in a short tract entitled La dichiaratione de molti luoghi dubbiosi d'Ariosto e d'alquanti del Pet[rarca]. Escusation fatta in favor di Dante, published in the same year in which the Christiade appeared (1539). In this work, Dante's style is defended against Bembo's attacks on the basis of the equivalence between the subject of poetry and its style. Since Dante's subject matter is uneven, his language is consequently difficult and less pleasant than Petrarch's. It is safe to assume that Sovaro was familiar with this debates; moreover, it is worth noting the role played by the publisher Cancer, who published both Venafro's Commentary and Di Falco's Rimario. ${ }^{67}$ Finally, one should not overlook the fact that Di Falco was himself involved in contemporary religious debates. His work, Descrittione dei luoghi antichi di Napoli (1548/1549), has been described by Tobia Toscano as an apology for Naples, directed at the emperor Charles V, aiming especially at confirming the city's loyalty and its religious orthodoxy after the 1547 rebellion against the Inquisition. Nonetheless, as

\footnotetext{
${ }^{65}$ Ibid., c. 59 r.

${ }^{66}$ Ibid., c. $34 \mathrm{v}$.

${ }^{67}$ See fur further bibliography, Mauro Marrocco, 'Modernità implicate: antichi e moderni nella riflessione linguistica e grammaticale del primo Cinquecento napoletano', in Moderno e modernità: la letteratura italiana, Atti del XII Congresso dell'Associazione degli Italianisti, Roma, 17-20 settembre 2008, a cura di Clizia Gurreri, Angelo Maria Jacopino, Amedeo Quondam Lame: Lapienza, http://www.italianisti.it/upload/userfiles/files/Marrocco\%20Mauro-1(1).pdf; Tobia R. Toscano, 'Due schede per Benedetto di Falco', Critica letteraria, 19 (1991), pp. 725-759 (then in his volume ); Vincenzo Tisano, 'Dante, Bembo e la grammatica volgare del Cinquecento in uno sconosciuto opuscolo del napoletano Benedetto Di Falco', Rivista di Letteratura italiana, 8 (1990), pp. 595-637.
} 
the same Toscano points out, the author seems to sympathize with the Valdesian circles and, especially, with the Cassinese congregation to which don Benedetto Fontanini, the author of the Beneficio di Cristo, belonged. ${ }^{68}$

\section{Christocentric poems in the early Cinquecento: Venice and Naples}

One might legitimately wonder why Sovaro chose to write a poem dealing with the life of Christ. In fact, beginning in the late fifteenth century, a new trend for Christian epic arose in Italy and a number of Latin epics devoted to the life of Christ began to appear. Among them are the De Christi Passione carmen Iesuida nuncupatum by Girolamo delle Valli (composed around 1445 and first printed in Augsburg in 1471), Macario Muzio's De triumpho Christi (first printed in 1499), the posthumous Parthenias liber in divae Mariae historia by Marco Probo dei Mariani (published in 1524, 25 years after Mariani's death in 1499), and the De rebus ac gestis Christi by the Dalmatian Giacomo Bona (1526). All these poems were written in Latin, as were the two sixteenth-century masterpieces in the field of biblical epic: Jacopo Sannazaro's De partu Virginis (1526) and Marco Girolamo Vida's Christias (1535).

In the first half of the sixteenth century, along with these humanistic works, a large number of vernacular poems on the life of Christ were published, which drastically decreased in the second half of the century. One might well consider this to be a consequence of the replacement of a risky form of Christocentric devotion that characterized the first four decades, with more acceptable forms of devotion to the Virgin, the rosary, the saints and martyrs. In addition, a poem devoted to Christ was supposed to strictly adhere to the Gospel, thus inevitably overlapping with the prohibition on translating the Bible into the vernacular that came into force in 1559 with the first Index of prohibited books, which, nonetheless, established that permission to read could be granted to laymen (but not to women). However, it appears plausible that before the Council of Trent poems dealing with the life of Christ were largely sought after, given the considerable number of such works printed over the first four decades of the century. Among them, one might include Teofilo Folengo's La Umanità del Figliuolo di Dio (1533, whilst his La Palermitana remained unpublished and unfinished), Giuseppe Fedeli Catonello's Opera spirituale in versi, intitolata Fonte del Messia (1531), Giovanni del Bene's La resurrettione et ascensione del nostro signor Iesù Christo (15501552), Matteo Caldo's Vita Christi Salvatoris eiusque Matris Sanctissime senariis rhithmis (in the vernacular despite the title, and printed in Venice by Augustino Bindoni in 1555, although the poem had been written in 1492), followed by a sequel by Francesco Maurolico entitled De gestis apostolorum (1556).

These works enhanced devotion, raised the readers' curiosity and presented complicated theological issues in an accessible way. The most interesting of them is possibly Teofilo Folengo's La umanità del figliuolo di Dio, first published in 1533 and subsequently reprinted in 1567 and 1578. Unlike the other mentioned authors, Folengo clearly states the reasons underlying his decision to try his hand at writing such a poem. The introduction to the Umanità can be read as a sort of a manifesto for the genre, and helps us to understand what a biblical poem could offer to contemporary readers. First of all, Folengo's choice to write in ottava rima has been inspired by the example of Ariosto, who had died just a few months before and who is lovingly remembered in the introduction. As a consequence, in a totally unprecedented way, a devotional work is directly compared to a bestselling romance like the Orlando Furioso (whose definitive version had appeared in 1532). ${ }^{69}$

\footnotetext{
${ }^{68}$ Toscano, Due schede, pp. 736-740. The praise of the Cassinese congregation is heavily censored in the later editions: for example, in that published in Naples, Gio. Battista Cappelli, 1589. Interestingly, the encomium of the old preachers preaching the Gospel and explaining St Paul's epistles to the people has escaped the censor's attention.

${ }^{69}$ Teofilo Folengo La Umanità del Figliuolo di Dio, a cura di Simona Gatti Ravedati (Alessandria: Edizioni Dell'Orso, 2000), p. 134.
} 
In the same introduction Folengo explains his peculiar technique, which has been that of picking up from the well ordered "evangelical history" some of Christ's deeds, devoutly arranging them in a new and different order, enriching them with additions springing from his imagination. ${ }^{70}$ In 1533 Folengo had just been re-admitted to the Cassinese Congregation of the Benedictine order after a period spent in Venice (1525-30) and after being sentenced to a period of three years of hermitage, the last part of which he spent at Punta Campanella, close to Naples, where he became acquainted with, among others, Girolamo Seripando and Vittoria Colonna. Although Folengo presents his poem as a penitential work, mainly directed to his brothers of the monastery of San Benedetto Po near Mantua, his intention was to reach a broader public.

As Giambattista, Folengo's brother and a theologian himself, affirms in one ottava which precedes the text, the Umanità is meant to reveal the content of the Gospel in vernacular, in a pleasant way, making it accessible to a vast audience:

Voglion non so quai saggi che 'l Vangelo
Non mai debbiasi esporre al volgo in carte
Con stil volgar, però ch'a lui già il velo
Del tempio ascose la più santa parte.
Rispondo che, morendo, il Re del cielo
Squarciollo d'alto a basso acciò che sparte
Sian or sue grazie al nobil, al plebeo,
Tartaro, Indo, Latin, Greco, Afro, Ebreo.

As a Cassinese monk, Folengo shared the theological beliefs expressed in the Beneficio di Cristo. Therefore, in his poem he focused on the complementary mysteries of the Incarnation and death of Christ. In order to make them fully accessible to his readers, he enriched the work with an iconographic apparatus. On the title-page, a woodcut shows Christ healing a leper; after the introduction, another woodcut displays the Virgin adoring the Child, whilst the angels carry the instruments of the Passion. At the end of the book, Folengo placed another woodcut, Mantegnesque in style, showing the entombment of Christ; on the tomb appears the motto mors tua vita mea, whilst underneath the woodcut it reads huius livore sanati sumus (a quotation from Isaiah 53.4 which had also been echoed in the Beneficio di Cristo). Folengo's attempt to make his text fully comprehensible to a large public and possibly to prevent criticism is also clear from the glosses which accompany the text providing the evangelical sources from which he is drawing.

The Umanità is perhaps the first vernacular biblical poem of a certain length and complexity; Folengo here resorts to Ariosto as an authority; he also tries to overcome the inevitable linear movement of the biographical account by displacing the story either in heaven or in hell and inserting invectives, digressions, theological explanations, often touching upon such issues as the decadence of the Church or the relationship between faith and works. All these features make of the Umanità a brand new poem and a complex object of devotion which the reader could use in many ways: he could simply read it enjoying the story, he could use it to meditate, to study, or just to contemplate its illustrations. The case of Folengo's Umanità can be fruitfully compared to that of Sovaro's Christiade. ${ }^{72}$ Whilst Folengo seems to have a clear perception of the theoretical reasons underpinning the choice of the vernacular, of the ottava rima and, most of all, has a clear

\footnotetext{
70 "Ma non mi pare disdica però, se alcuno devoto Bernardo, mettasi a scegliere da la ordinata evangelica istoria o gesti o documenti del nostro Salvatore, formandone un nuovo ordine con devoto discorso di più imaginate cose", Ibid., pp. 132-3; on this work see Simona Gatti, 'Su "La umanità del figliuolo di Dio" di Teofilo Folengo', Giornale Storico della Letteratura Italiana, 168, 1991, pp. 1-53; Ead., 'L'ottava rima nell'“Umanità del Figliuolo di Dio"”, in Teofilo Folengo nel quinto centenario della nascita, Atti del Convegno, Mantova-Brescia-Padova, 26-29 settembre 1991, a cura di Giorgio Bernardi Perini e Claudio Marangoni (Florence: Olschki, 1993), pp. 119-39.

${ }^{71}$ Ibid., p. 135.

${ }^{72}$ In 1535 Giovanni Domenico di Lega (1510 c.-?) had published a poem in ottava rima on the life of St Giacomo della Marca for the same Cancer that published the Christiade: Rime [...] in la vita del beato Giacomo dala Marca. The same author published a tragedy in 1549 entitled Morte di Christo.
} 
theological programme in mind, Sovaro is far more reticent on his choices. Most of all, Sovaro seems to distance himself from the on-going religious debate.

However Sovaro's poem followed in the footsteps of the recent but glorious Neapolitan tradition of Christian poetry. Some fifteen years before Sovaro Jacopo Sannazaro had published his De partu virginis (1526), a major work of religious poetry, widely appreciated but also harshly criticised for its deliberate use of pagan mythology. ${ }^{73}$ Moreover, in the same year - 1533 - that Folengo printed his Umanità, Scipione Capece, a good friend of Folengo's, published his poem on the life of St. John the Baptist entitled De Vate maximo, which was printed again in 1535 and in a new version in 1546. Capece, praised by such authors as Pietro Bembo and Bernardo Tasso, was an admirer of Bernardino Ochino and a protégé of the prince of Salerno, Ferrante Sanseverino and of his wife Isabella Villamarina. The author of a short poem De nativitate Domini, Capece is also credited with a lost work on the life of Christ, entitled, according to the eighteenth-century scholar Giammaria Mazzuchelli, Cristiade. ${ }^{74}$

\section{A literary precedent of Sovaro's Christiade: Marino Jonata's El giardeno spirituale}

Given all these poetic antecedents, one might suppose that Sovaro was prompted to write the Christiade not only by the desire to resist the diffusion of heretical beliefs and educate his readers in a more orthodox religion, but also to exploit a highly fashionable literary genre. Among these antecedents, one appears to be especially connected to the Christiade. Sovaro's decision to divide his work into precisely 106 canti seems to hint at another poem, also in terza rima and also in 106 canti printed in Naples some fifty years before the Christiade. This work, entitled El giardeno spirituale, was a religious poem written by a little known author, Marino Jonata. Its printed edition, which is nowadays quite rare (there are only four extant copies in Naples, Rome, Paris and London), made it known throughout the Kingdom of Naples where it became one of the few spiritual works in verse to be printed, at least according to Amedeo Quondam's repertory. ${ }^{75}$

Jonata was born in Agnone, in Molise, in 1400/1410 and died between 1465, when he finished his poem, and 1490 when his son Francesco had it printed. The autograph manuscript is kept in the Biblioteca Nazionale in Naples (ms. XIII.C.13); the first edition, printed by Cristianus Preller in Naples in 1490, lacks the rich marginalia of the manuscript. The poem, like Sovaro's, is Dantesque in style and written in the form of a dialogue between the author, Death personified and a friend of Jonata's, Nicolò Gizio. It is divided into three parts: the first tells of death, demons and angels, universal judgement, hell; the second deals with the punishments of the damned; the third with celestial hierarchies and the condition of the blessed souls. A notary, Jonata became a Franciscan

\footnotetext{
73 Attacks on Sannazaro's poem can be found in Erasmus' Ciceronianus (1528) and in Scipione Capece's De vate maximo, especially in the opening lines of the second book. It was subsequently fiercely criticized by Giulio Cesare Scaligero in his Poetices libri septem (1561); nevertheless, its mixture of pagan mythology and Christian subject was defended some thirty years later by Valentino Odorici in his commented edition of Sannazaro's works: Iacobii Sannazarii opera omnia Latine scripta, et in tres De Partu Virginis libros Valentini Odoricii Utinensi commentaria [...] (Venetiis: Apud Franciscum Franciscii, m. Senensium, 1593). For an overview of the reception of this work see Stefano Prandi's Introduction to Jacopo Sannazaro, De partu virginis. Il parto della vergine. Volgarizzamento di Giovanni Giolito de' Ferrari (1588) a fronte, a cura di Stefano Prandi (Rome: Città Nuova, 2001).

${ }^{74}$ The XVIII century scholar Giammaria Mazzuchelli gathered sixteenth-century testimony (mainly letters) from which we learn that Capece had entrusted a friend with a manuscript copy of the work: unfortunately, the manuscript was accidentally lost by the unnamed friend: Giammaria Mazzuchelli, Notizie storiche e critiche intorno alla vita e agli scritti di Scipione Capece patrizio napoletano, in Il poema de principiis rerum di Scipione Capece [...] colla traduzione [...] di Francesco Maria Ricci [...] dello stesso Capece il poema De vate maximo [...] (Venice: dalle stampe Remondiniane, 1753), pp. 26-27.

${ }^{75}$ Amedeo Quondam, 'Note sulla tradizione della poesia spirituale e religiosa (parte prima)', Studi (e testi) italiani, 16 (2005), Paradigmi e tradizioni, a cura di Amedeo Quondam, pp. 127-211 (p. 136); the article is followed by a Saggio di bibliografia della poesia religiosa (1471-1600); see also Marco Santoro, La stampa a Napoli nel Quattrocento (Naples: presso l'Istituto, 1984) and Anne Jacobson Schutte, Printed Italian vernacular religious books 1465-1550: A finding list (Genève: Droz, 1983).
} 
tertiary in 1434 under the influence of the preacher Giovanni da Capestrano: he was also an active member of the local Confraternita dei morti. It is from these influences, it has been suggested, that he derived his uncommon choice of presenting Death as a character in his work. ${ }^{76}$ The poem is dedicated to all devout Christians to teach them how to avoid eternal death. This extremely interesting work is clearly didactic in its purpose. Not only does it display a rich paratextual apparatus (Latin marginalia and a Tabula which is not simply a list of contents but rather an extremely well organized summary of the difficult theological issues discussed in the work, divided into schemes and subheadings), ${ }^{77}$ but the contents are often organized, as in a scholastic treatise, according to a rather fixed pattern: the author is struck by the things he sees and does not understand and asks Death for an explanation. The answer to his questions is normally divided into a series of reasons or causes (usually four). The marginalia provide further explanations and biblical sources for the most complex theological issues. They also sometimes convey information on Jonata's life, as in the case of the long account, in canto VII, of king Alphonso's entrance into Naples in 1443, which the author witnessed. The poem was perhaps originally intended to be circulated within a restricted circle, presumably the brothers of Jonata's Confraternity and his family. The harsh theological topic of the poem and the Latin marginalia, make it clear that the poet addressed a selected circle of learned readers. The stress on death, on suffering, on the horror of the decay of man's body, the descriptions of diabolical temptations, the continuous stress on the transience of everything that is human denote how Jonata's spirituality was still deeply medieval. In seeking to stimulate a strong emotional response from his readers, he appears to be closer to the religious poets of the thirteenth century and to his contemporary Franciscan preachers than to the refined humanists who were then flourishing at the court of Naples. ${ }^{78}$ Despite its paratextual apparatuses, Jonata's poem could address a restricted audience. Sovaro's Christiade was certainly more accessible to readers for the theological issues remained in the background and, when addressed, were dealt with resorting to metaphors, thus making them easily understandable.

\section{Some hypotheses on the audience of the Christiade and its use}

This leads to the one last point left to clarify. To what audience was the Christiade addressed? The rather plain account of Christ's deeds could potentially be accessible to (if not appealing for) a vast public; what is more, although the in-folio format was certainly expensive, this does not mean that the Christiade was necessarily an élite book. We can only speculate that Sovaro was mainly addressing an audience of learned men, who could afford buying this book: perhaps professionals (lawyers, physicians, as these categories were often implied in matters of heresy, as testified to by the great trials of the $1550 \mathrm{~s}$ - the trial of Giovanni Morone, that of Pietro Carnesecchi, etc.), possibly in order to prevent them from reading the dangerous books that were being circulated at that time. In order to formulate a more accurate hypothesis on the audience, we need to know more about private libraries in Naples in the mid-Cinquecento and the presence of devotional books. That would require extensive research through archival - and mainly notarial - records. Carlo De Frede has published the inventories of some physicians' and lawyers' libraries at the end of the Quattrocento, in which devotional books are barely represented. In the inventory of Antonio Solimena's library (71 books), drafted before Solimena's death on the 8th of November, 1486, we

\footnotetext{
${ }^{76}$ See Philine Heleas, 'Jonata (Gionata), Marino', in Dizionario biografico degli italiani, vol. 62 (Rome: Istituto dell'Enciclopedia Italiana, 2004), pp. 567-568; Eugenio Ragni, 'Jonata, Marino', in Enciclopedia dantesca, vol. 3 (Rome: Istituto dell'Enciclopedia Italiana, 1971), pp. 502b-503a.

${ }^{77}$ The Tabula is published, along with the first seven cantos, in Francesco Ettari, El giardeno di Marino Jonata agnonese. Poema del secolo XV (Naples: Stab. Tipografico del Cav. Antonio Morano, 1885); see also Francesco Ettari, El Giardeno of Marino Jonata Agnonese. An Italian Poem of the Fifteenth Century (New York: Columbia University Press, 1924).

${ }^{78}$ See Adelmo Macchioni, ‘Il dantismo “osservante” di Marino Ionata', Italianistica, 29 (2000), pp. 27-41.
} 
find listed a "Viatico, in carta de coyro", perhaps a book analogous to that listed in Antonio Damiani's library inventory: "un altro libro, quale ey de carta de coyro, quale comecza «Liber Viatici»"; ${ }^{80}$ in the same inventory appears a "officiolo de la Vergene Maria, meniato de oro, colle zappe de argento". ${ }^{81}$ At the end of the sixteenth century, many librarians still held vernacular versions of the Bible and other devotional books, as we know from an Inquisitorial document held in the Sant'Uffizio Archive in Rome. In 1598 the Inquisitor Cherubino da Verona visited a number of booksellers shops and found that many prohibited books were still present: vernacular versions of the Bible as well as works by Savonarola, the Hortulus animae, the Monte Calvario. ${ }^{82}$ This is not surprising at all, since, as Gigliola Fragnito has pointed out, "la versione integrale della Bibbia o il solo Nuovo Testamento, insieme agli scritti volgari di argomento biblico costituivano [...] la categoria di libri proibiti più presente". ${ }^{83}$ As in the many other cases highlighted by Fragnito, the survival of vernacular versions of the Bible, despite inquisitorial prohibitions, testifies to people's long-lasting attachment to the Holy Scripture. This makes it even more understandable that Sovaro would attempt to try his hand at a poem directly based on the Gospel in a time when direct translations of the Bible were not yet prohibited. Later on, although Sovaro's work never appeared on an Index of Prohibited Books, his work came under suspicion. It is mentioned in a list of books belonging to the bookseller Antonio Pisacane, drafted in 1579 and held in the Archivio Storico Diocesano in Naples. Here Sovaro's work is listed as follows: "Francisco Soveto [sic] napolitano sopra li evangeli in folio"; the entry is preceded by a cross meaning that the book could not be sold without ecclesiastical licence. ${ }^{84}$

However, it should be noted that by linking his text to the Gospels recited throughout the liturgical year, Sovaro allows us to connect the Christiade with the tradition of the so-called Epistole et evangeli. In the aforementioned list of prohibited books drafted by Cherubino da Verona an impressive number of such works is recorded. The Epistole et evangeli, widely printed over the XV and XVI centuries, provided the texts of the Sunday lectures during the liturgical year; they were also frequently illustrated. They were certainly an object of domestic devotion since they allowed the reader to prepare him or herself for Mass or to meditate on it within the domestic space. These works, also known as lezionari, became popular from the XIII century and in the Cinquecento were also used as primers. An inquisitorial decree issued on the $22^{\text {nd }}$ of November 1596 established that the Epistole et evangeli, despite containing the otherwise prohibited text of the Scripture, could be read with permission of the local bishop, or of the parish priest, or of an inquisitor. Yet the Inquisition's decision was not made it public until the early 1597, and even then not systematically. It was also decided that the only acceptable vernacular translation of passages from the Scripture should be that of Remigio Nannini (1567). If in the XV century the Epistole et evangeli contained the gospel text alone, in the following years a number of comments, parables and meditations on the life of Christ began to be added. Whilst these works offered some kind of compensation for the disappearance of the Bible, and provided the low clergy, often relatively uneducated, with a useful didactic tool, they could also come to include heterodox or superstitious ideas. ${ }^{85}$ Sovaro's

\footnotetext{
${ }^{79}$ Carlo De Frede, Biblioteche di giuristi e medici napoletani del Quattrocento (Naples: Tipografia De Frede, 1973), p. 31.

${ }^{80}$ Ibid., p. 36.

${ }^{81}$ Ibid., p. 37. Damiani was a professor at the Studio in Naples. He was already dead by the year 1499: his library included 31 works. The physician Giovanni Francesco Brancaleone, who was trialled in 1569, owned four hundred books, among which many were prohibited: see Lopez, Inquisizione stampa e censura, p. 62.

${ }^{82}$ Archivio della Congregazione per la Dottrina della Fede (ex Sant'Uffizio), Indice, XVIII/1, cc. 39r-40r, Libri in Bibliothecis Neapolitanae civitatis prohibiti vel suspensi per indicem novum Romanum, anno praeterito 1598 visitatis per P. Magistrum Veronensem theologum Curiae Archiepiscopalis Neapolitanae.

${ }^{83}$ Fragnito, La Bibbia al rogo, p. 280; see also pp. 281-84.

${ }^{84}$ Lopez, Inquisizione stampa e censura, pp. 311 and 107-27.

${ }^{85}$ See Fragnito, La Bibbia al rogo, pp. 292-302; Ead., Proibito capire, pp. 226-27; Danilo Zardin, 'Bibbia e letteratura religiosa in volgare nell'Italia del cinque-seicento', Annali di Storia moderna e contemporanea, 4 (1998), pp. 593-616; Edoardo Barbieri, 'Fra tradizione e cambiamento: note sul libro spirituale del XVI secolo', in Libri biblioteche e cultura nell'Italia del Cinque e Seicento, a cura di Edoardo Barbieri e Danilo Zardin (Milan: Vita \& Pensiero, 2002), pp. 3-61
} 
Christiade, in a sense, re-establishes the purity of the gospel text, connecting it to the Sunday mass. It may be that different traditions merged in his work: the relatively new fashion for biblical poems; the genre of the Epistole et evangeli; and, finally, that of the so-called armonie evangeliche, which was at the basis of some medieval and early-modern best-sellers such as Ludolph of Saxony's Vita Christi.

It is clear that Sovaro's literary work was complex and multi-layered, and deserves historiographical reassessment. If on the one hand the tradition of the Epistole et evangeli offered the text of the Gospel but lacked a narrative, on the other hand Ludolph Saxony's Vita Christi was written entirely in Latin (it was first translated into the vernacular by Francesco Sansovino in 1570). Sovaro presented the reader with a potentially captivating vernacular work, reminiscent of Dante's example and, at the same time, he produced an invaluable tool for approaching the Gospel and practicing domestic and public devotion. Whatever the audience of the Christiade, it seems likely that its readers could either read it in its entirety as a poem, or peruse it as a form of handbook. Thanks to the paratextual apparatus, it was easy to browse the work. Thus, the text could become an object of domestic devotion: the devout reader could read the Gospel of the following or of the past Sunday, spiritually preparing him or herself or meditating upon what he or she had heard at church. The Christiade could certainly be the object of group reading and meditation. However, the absence of comments, even in the form of glosses, and the rarity of theological digressions, if on the one hand they fostered an intense and exclusive meditation on the life of Christ, on the other hand required a competent reader, one who was able to move from Sovaro's text to the Gospel. It is likely, therefore, that the Christiade was not meant to replace the reading of the Gospel; rather, it was a sort of introduction to it, which could prompt and urge devotees to access the New Testament.

What is striking is the strong focus on the Mass and the Gospels, particularly on their reliability as a source. This could be considered to be a prompt response, on the part of a local author, to the religious ideas spreading through Naples at the time. As has been demonstrated, this was a period when the authority of the Gospels was being questioned. Furthermore, from Valdesian teaching certain radical ideas had been fomented, among which "che le messe son profane, et che son idolatria et chi ce va fa idolatria" and "che le Scripture sancte et evangeliche siano false perché si ritrova alcuna contradditione in esse non tamen vere ma certo modo apparente". ${ }^{86}$ These ideas were spread not only among commoners but also among the higher social ranks. Sovaro was surely well aware of this context and might have thought of countering such ideas by means of a devout, Christocentric work disguised as one of the then highly fashionable Christian poems. Furthermore, as Gigliola Fragnito has shown, during the first decades of the sixteenth century the rise of a new kind of vernacular preaching, centred on the Scripture, completely different from the old, obscure Thomistic way of preaching, contributed to the establishment of a new relationship between laymen and the Bible. ${ }^{87}$ We have evidence of the laity reading the Bible before and after attending sermons in order to better understand and memorize them. Attendance at sermons was preferred to Mass, which was in Latin and thus less appealing to common people. We might infer that Sovaro also had in mind an attempt to invert this phenomenon, given the risky contents of Ochino's and other preachers' sermons. The Christiade, with its didactic apparatus, could help laymen and women to understand the Mass and divert them away from more dangerous doctrines. In other words, Sovaro appropriated the same tools that were leading people astray from the path of orthodoxy in order to restore them to traditional devotion.

(esp. p. 14); Federica Dallasta, Eredità di carta. Biblioteche private e circolazione libraria nella Parma farnesiana (1545-1731), prefazione di Giorgio Montecchi (Milan: Franco Angeli, 2010), pp. 197 and 336.

${ }^{86}$ Quoted in Addante, Eretici e libertini, pp. 21 and 23.

${ }^{87}$ Fragnito, La Bibbia al rogo, pp. 65-69. 